\title{
Chemical Composition and Nutritional Value of Some Type of Wild Mushrooms in Blue Nile State
}

\author{
Ibrahim Ishag Ibrahim Omer ${ }^{1, ~}$, Ebrahim Alfaig Alnoor Alfaig ${ }^{2}$ \\ ${ }^{1}$ Ministry of Agriculture Animal Resources and Forestry, Department of Horticulture, Damazin, Blue Nile State, Sudan \\ ${ }^{2}$ Department of Food Science and Technology, College of Agricultural Studies, Sudan University of Science and Technology, Khartoum, \\ Sudan
}

Email address:

ibrahimishag1@yahoo.com (I. I. I. Omer)

${ }^{*}$ Corresponding author

\section{To cite this article:}

Ibrahim Ishag Ibrahim Omer, Ebrahim Alfaig Alnoor Alfaig. Chemical Composition and Nutritional Value of Some Type of Wild Mushrooms in Blue Nile State. International Journal of Food Science and Biotechnology. Vol. 5, No. 2, 2020, pp. 12-20.

doi: $10.11648 / j . j \mathrm{jfsb} .20200502 .12$

Received: April 10, 2020; Accepted: April 26, 2020; Published: May 15, 2020

\begin{abstract}
This study was conducted to determine the chemical composition and nutritional value for eight samples of edible mushrooms, including seven samples of wild edible mushrooms collected from Blue Nile State and one commercial sample. All samples were classified by Mycokey software program and mushroom expert web site. In addition, the mushrooms varieties found are Agaricus bisporus, Chlorophyllum rhacodes, Agaricus lutosus, Volvariella volvacea, Agaricus impudicus, Agaricus arvensis, Agaricus silvicola and the commercial sample (Agaricus bisporus). Also, toxicity was detected using potassium hydroxide (4\%) during collection in the field and for all samples the toxicity test was negative. The results showed that the samples containing varying moisture content between samples ranged from $5.26 \%$ to $11.11 \%$. Fat content ranged from $0.94 \%$ to $2.99 \%$. Protein content ranged between $19.41 \%$ to $34.14 \%$. Ash content ranged from $0.22 \%$ to $1.47 \%$. Add to that, the fiber content ranged from $5.25 \%$ to $23.86 \%$. Carbohydrate content ranged from $26.76 \%$ to $77.91 \%$. The calcium content $(\mathrm{mg} / \mathrm{kg})$ ranged from 5.80 to 8.60 . The magnesium content $(\mathrm{mg} / \mathrm{kg})$ ranged from 3.07 to 5.50 . The phosphorus content $(\mathrm{mg} / \mathrm{kg})$ ranged from 2.15 to 2.50 . The potassium content $(\mathrm{mg} / \mathrm{kg})$ ranged from 21.20 to 21.50 . The iron content $(\mathrm{mg} / 100 \mathrm{~g})$ ranged from 1.30 to 1.55 . The zinc content $(\mathrm{mg} / 100 \mathrm{~g})$ ranged from 0.51 to 0.52 . The copper content $(\mathrm{mg} / 100 \mathrm{~g})$ ranged from 0.10 to 0.11 . The manganese content $(\mathrm{mg} / 100 \mathrm{~g})$ ranged from 0.10 to 0.12 . The essential amino acids content $(\mathrm{mg} / 100 \mathrm{~g})$ of mushroom samples were: arginine content ranged from 6.30 to 6.40. Histidine content ranged from 1.90 to 2.20. Lysine content ranged from 5.00 to 5.10 . Tryptophan content ranged from 0.88 to 0.90 . Phenylalanine content ranged from 2.00 to 2.10. Methionine content ranged from 1.00 to 1.15 . Threonine content ranged from 4.05 to 4.10. Leucine content ranged from 3.90 to 4.10. Isoleucine content ranged from 5.56 to 5.70. Valine content ranged from 4.20 to 4.50. All samples contain high levels of protein, minerals and essential amino acids. However, the Volvariella volvacea sample is the best sample in terms of containing the protein so it can be entered as a dietary supplement in some processed foods that contain very small amounts of protein.
\end{abstract}

Keywords: Wild Mushrooms, Chemical Composition, Nutritional Value, Minerals, Amino Acids

\section{Introduction}

Mushrooms are the fruiting bodies of macro-fungi. They include both edible/medicinal and poisonous species. However, originally, the word "mushroom" was used for the edible members of macro-fungi and "toadstools" for poisonous ones of the "gill" macro-fungi. Scientifically the term "toadstool" has no meaning at all and it has been proposed that the term is dropped altogether in order to avoid confusion and the terms edible, medicinal and poisonous mushrooms are used.

Mushroom nutriceuticals describe a new class of compounds extractable from either the mycelium or the fruit body of mushrooms and embody both their nutritional and medicinal features. They are consumed as a dietary supplement that has potential therapeutic applications [8].

Mushroom Nutriceuticals are enriched food materials that 
are used for the maintenance of a healthy diet. These are part of a meal [8, 19].

Infusion of mushrooms has been used to prevent beriberi. In addition, the decoction has been used for the treatment of abscesses and wounds [29].

Edible mushrooms once called the "food of the gods" and still treated as a garnish or delicacy can be taken regularly as part of the human diet or be treated as healthy food or as a functional food. The extractable products from medicinal mushrooms, designed to supplement the human diet not as regular food, but as the enhancement of health and fitness, can be classified into the category of dietary supplements/mushroom nutriceuticals [7].

Wild mushrooms have been extensively consumed since the primers of human civilization, due to their unique and delicate flavor, being rich sources of minerals and having high amounts of water, protein, fiber, and carbohydrates. Lipids are present in low values, which make them excellent to be included in low-calorie diets (Heleno et al., 2009; Kalac, 2012).

Beyond the nutritional characteristics, mushrooms have been also extensively studied for their medicinal properties, mainly due to their richness in bioactive compounds that presented antioxidant, anticancer and antimicrobial properties, among other bioactivities [13, 14].

Dietary supplements are ingredients extracted from foods, herbs, mushrooms and other plants that are taken without further modification for their presumed health-enhancing benefits.

Identification study help to assure the safe use of mushroom as food. Moreover, this study is considered a pioneer study aimed to shed some light on some of the wild species of mushrooms in Blue Nile State that are used as edible mushrooms by the local people and the intervention of food supplements in diets that are deficient of protein.

Many local people in Blue Nile State taking some types of wild edible mushrooms, collecting the mushroom during the begging of the rainfall season, consuming it fresh or drying it and using it in steaks of the dried meat (shormot) in their food, did not have a food culture that will enable them to know that these species contain a toxin or not. This study was conducted to identify some of the species of wild edible mushrooms in Blue Nile state and the determination of nutritional value, minerals, and essential amino acids and learn about their toxicity. To ensure the safety of the food supplement them.

General objective:

To study experimentally some wild mushroom and their suitability for human consumption.

\section{Materials and Methods}

\subsection{Materials}

Sample Collection

Seven samples of wild edible mushrooms were collected from Blue Nile State - the city of Al-Damazin in addition to one sample was purchased from super-market in Khartoum North. During the collection process from the field the toxicity test was conducted for all samples by potassium hydroxide with a concentration of $4 \%$ using dropper on the caps and stem, during this test there was no positive toxicity in all samples.

\subsection{Methods}

\subsubsection{Toxicity Test}

According to the mushroom expert web site (2008) was used Chemical tests in mushroom identification are methods that aid in determining the variety of some fungi. The most useful tests are potassium hydroxide (KOH) $3 \%$ to $5 \%$. On to attend $(\mathrm{KOH})$ weighing $4 \mathrm{~g}$, then dissolved in part of distilled water and then complete volume to $100 \mathrm{ml}$ with distilled water. Then $(\mathrm{KOH})$ solution was used for the detection of toxicity by dropping one or two drops of $\mathrm{KOH}$ solution into pieces of the caps and stem samples of the mushroom and then the color change was observed (no color change that means negative reaction).

\subsubsection{Identification of Mushroom Samples}

In this study, mushroom samples were identified by mycokey software program (is a synoptic multi-access key for identification of fungi and includes the Funga Nordica analytic keys) and mushroom expert web site.

\subsubsection{Preparation of Samples}

The samples collected between April and September 2016 from the city of Al-Damazin nursery. After it was dried in the shade at room temperature and then was crushed by blender and saved in plastic bags, then the bags were packed in aluminum foil until chemical analysis.

\subsubsection{Chemical Analysis}

The samples were analyzed for moisture, fat, Ash and fiber, using the AOAC procedures (AOAC, 2003). The crude protein $(\mathrm{N} \times 4.38)$ was determined in all samples by micro Kjeldahl technique following the method of AOAC (2005).

Total carbohydrates were calculated by difference according to the following equation:

$$
\begin{gathered}
\text { Total carbohydrates }=100 \%-(\text { Moisture }+ \text { Protein }+ \text { Fat }+ \\
\text { Ash }) .
\end{gathered}
$$

Mineral content was determined in all samples by Elmer (1996). Using the atomic absorption spectrophotometer model 210 VGP USA (AAS 2005).

Amino acid content was determined according to the official method of the AOAC (2006). Performed by using High-Performance Liquid Chromatography (HPLC).

\subsubsection{Statistical Analysis}

The results were subjected to statistical analysis (SAS). One-way by using a completely randomized design (CRD). The mean values were also tested and separated by using Duncan's Multiple Range Test (DMRT) as described by Montgomery and Douglas, (2001). 


\section{Results and Discussion}

\subsection{Identification of Mushroom Species}

All of the following plates from 1 to 8 were the field pictures of the studied mushroom samples collected from Blue Nile State and the commercial one. They identified by using Mycokey software program and mushroom expert web site.

\subsection{Moisture Content}

Table 1, figure 1 and figure 2 shows the moisture contents of wild edible mushrooms Agaricus bisporus, Chlorophyllum rhacodes, Agaricus lutosus, Volvariella volvacea, Agaricus impudicus, Agaricus arvensis, Agaricus silvicola, (Agaricus bisporus commercial sample). The highest moisture content $11.11 \%$ was in Volvariella volvacea, Agaricus arvensis and Agaricus silvicola, whereas the lowest $5.26 \%$ was in Agaricus bisporus, Chlorophyllum rhacodes, Agaricus lutosus, Agaricus impudicus and the commercial sample (Agaricus bisporus), respectively. There were no significant differences $(\mathrm{P} \leq 0.05)$ between the varieties Agaricus bisporus, Chlorophyllum rhacodes, Agaricus lutosus, Agaricus impudicus and the commercial sample (Agaricus bisporus), regarding moisture content, while between the varieties Volvariella volvacea, Agaricus arvensis, Agaricus silvicola there was no significant differences $(\mathrm{P} \leq 0.05)$ in moisture content. Abdalla (2015) [1] reported that the moisture content of some wild edible mushrooms ranged between $6.97 \%$ and $14.07 \%$ also Saiqa et al., (2008) [18] reported that the moisture content of wild edible mushrooms was in Agaricus bisporus was $5.9 \%$ and moisture content $9 \%$ for the variety Volvariella volvacea was reported by Mshandete and Cuff (2007)[15].

\subsection{Fat Content}

Table 1, figure 1 and figure 2 shows the fat contents of wild edible mushrooms Agaricus bisporus, Chlorophyllum rhacodes, Agaricus lutosus, Volvariella volvacea, Agaricus impudicus, Agaricus arvensis, Agaricus silvicola and the commercial sample (Agaricus bisporus). The highest value of fat content was in Agaricus lutosus 2.99\%, whereas the lowest value of fat content was in Agaricus impudicus $0.94 \%$. The values within all samples showed a significant difference $(\mathrm{P} \leq 0.05)$. Abdalla (2015) [1] reported that the fat content of some wild edible mushrooms in (Agaricus bisporus) was 3.50\% and Mshandete and Cuff (2007) [15] reported the fat content in Volvariella volvacea was $3.3 \%$ and Barros et al., (2007) [6] reported the fat content in Agaricus arvensis was $2.7 \%$.

\subsection{Protein Content}

Table 1, figure 1 and figure 2 shows the protein contents of wild edible mushrooms Agaricus bisporus, Chlorophyllum rhacodes, Agaricus lutosus, Volvariella volvacea, Agaricus impudicus, Agaricus arvensis, Agaricus silvicola and the commercial sample (Agaricus bisporus). The highest value of protein content was in Volvariella volvacea $34.14 \%$, whereas the lowest value of protein content was in Agaricus bisporus $19.41 \%$. The values within the Agaricus bisporus, Chlorophyllum rhacodes, Agaricus lutosus, Volvariella volvacea, Agaricus impudicus and the commercial sample (Agaricus bisporus) showed significantly difference $(\mathrm{P} \leq 0.05)$. While the samples Agaricus arvensis, Agaricus silvicola are similar in values and have no significant difference between them. Abdalla (2015) [1] reported that the protein content of Agaricus bisporus was $21.35 \%$, another study conducted by Saiqa et al., (2008) [18] reported that the protein content in Agaricus bisporus was 16.4\% and Mshandete and Cuff (2007) [15] reported the protein content in Volvariella volvacea was $28.0 \%$ and Barros et al., (2007) [6] reported the protein content in Agaricus arvensis was $56.3 \%$.

\subsection{Ash Content}

Table 1, figure 1 and figure 2 shows the ash contents of wild edible mushrooms Agaricus bisporus, Chlorophyllum rhacodes, Agaricus lutosus, Volvariella volvacea, Agaricus impudicus, Agaricus arvensis, Agaricus silvicola and the commercial sample (Agaricus bisporus). The highest value of the ash content was in Agaricus bisporus $1.47 \%$, whereas the lowest value of ash content was in Agaricus impudicus $0.22 \%$. The values within all samples showed a significant difference ( $\mathrm{P} \leq 0.05)$. Abdalla (2015) [1] reported that the ash content of Agaricus bisporus was $26.00 \%$ and Saiqa et al., (2008) [18] founded the ash content in Agaricus bisporus as $11.01 \%$ and Mshandete and Cuff (2007) [15] reported the ash content in Volvariella volvacea was $10.0 \%$ and Barros et al., (2007) [6] reported the ash content in Agaricus arvensis was $3.5 \%$.

\subsection{Crude Fiber Content}

Table 1, figure 1 and figure 2 shows the crude fiber of wild edible mushrooms Agaricus bisporus, Chlorophyllum rhacodes, Agaricus lutosus, Volvariella volvacea, Agaricus impudicus, Agaricus arvensis, Agaricus silvicola and the commercial sample (Agaricus bisporus). The highest value of crude fiber was in Agaricus impudicus was $23.86 \%$, whereas the lowest value of crude fiber was in Agaricus silvicola $5.25 \%$. The values within the Agaricus bisporus, Volvariella volvacea, Agaricus impudicus, Agaricus arvensis and Agaricus silvicola showed significantly difference $(\mathrm{P} \leq 0.05)$. While the Chlorophyllum rhacodes, Agaricus lutosus and the commercial sample (Agaricus bisporus) are similarity in values and have no significant difference. Abdalla (2015) [1] reported that the crude fiber content of Agaricus bisporus was $14.33 \%$ and Mshandete and Cuff (2007) [15] reported the fiber content in Volvariella volvacea was $9.8 \%$.

\subsection{Carbohydrate Content}

Table 1, figure 1 and figure 2 shows the carbohydrate contents of wild edible mushrooms Agaricus bisporus, Chlorophyllum rhacodes, Agaricus lutosus, Volvariella volvacea, Agaricus impudicus, Agaricus arvensis, Agaricus 
silvicola and the commercial sample (Agaricus bisporus). The highest value was in Agaricus bisporus was $77.91 \%$, followed by Agaricus lutosus $54.01 \%$, whereas the lowest value of carbohydrate content was in Agaricus impudicus was $26.76 \%$. The values within all samples showed significantly difference $(\mathrm{P} \leq 0.05)$. Abdalla (2015) [1] reported that the carbohydrate content of some wild edible mushrooms in Agaricus bisporus was $20.75 \%$ and Saiqa et al., (2008) [18] reported that in Agaricus bisporus was $56.47 \%$ and Mshandete and Cuff (2007) [15] reported the carbohydrate content in Volvariella volvacea was $50.0 \%$ and Barros et al.,(2007) [6] reported the carbohydrate content in Agaricus arvensis was $37.5 \%$.

\subsection{Mineral Content}

Table 2, figure 3 and figure 4 shows the calcium contents of wild edible mushrooms Agaricus bisporus, Chlorophyllum rhacodes, Agaricus lutosus, Volvariella volvacea, Agaricus impudicus, Agaricus arvensis, Agaricus silvicola and the commercial sample (Agaricus bisporus). The highest levels of calcium were in Agaricus lutosus was $8.60 \mathrm{mg} / \mathrm{kg}$, whereas the lowest levels of calcium were in Volvariella volvacea was $5.80 \mathrm{mg} / \mathrm{kg}$. The values within the Agaricus bisporus, Chlorophyllum rhacodes, Volvariella volvacea, Agaricus impudicus, Agaricus silvicola and the commercial sample (Agaricus bisporus) showed significantly difference ( $\mathrm{P}>0.05)$. While the Agaricus lutosus, Agaricus arvensis and the commercial sample (Agaricus bisporus) are similar in values. The reported calcium values for Agaricus bisporus are $6.7 \mathrm{mg} / \mathrm{kg}$, (Abdalla, 2015) [1].

Table 2, figure 3 and figure 4 shows the magnesium content of wild edible mushrooms. The highest levels of magnesium were in Agaricus lutosus was $5.50 \mathrm{mg} / \mathrm{kg}$, whereas the lowest levels of magnesium were in Volvariella volvacea was $3.07 \mathrm{mg} / \mathrm{kg}$.

Table 2, figure 3 and figure 4 shows the phosphorus content of wild edible mushrooms. The highest levels of phosphorus were in Volvariella volvacea was $2.50 \mathrm{mg} / \mathrm{kg}$, whereas the lowest levels of phosphorus were in Agaricus silvicola was $2.15 \mathrm{mg} / \mathrm{kg}$.

Table 2, figure 3 and figure 4 shows the potassium content of wild edible mushrooms. The highest levels of potassium were in Agaricus arvensis was $21.50 \mathrm{mg} / \mathrm{kg}$, whereas the lowest levels of potassium were in Agaricus silvicola was $21.20 \mathrm{mg} / \mathrm{kg}$.

Table 2, figure 3 and figure 4 shows the iron content of wild edible mushrooms. The highest levels of iron were in Agaricus bisporus was $1.55 \mathrm{mg} / 100 \mathrm{~g}$, whereas the lowest levels of iron were in Volvariella volvacea was 1.30 $\mathrm{mg} / 100 \mathrm{~g}$.

Table 2, figure 3 and figure 4 shows the zinc content of wild edible mushrooms. The highest levels of zinc were in Volvariella volvacea $0.52 \mathrm{mg} / 100 \mathrm{~g}$, whereas the lowest levels of zinc were in the commercial samples (Agaricus bisporus) was $0.51 \mathrm{mg} / 100 \mathrm{~g}$.

Table 2, figure 3 and figure 4 shows the copper content of wild edible mushrooms in this study the highest levels of copper was in Agaricus bisporus was $0.11 \mathrm{mg} / 100 \mathrm{~g}$, whereas the lowest levels of copper was in the commercial samples (Agaricus bisporus) was $0.10 \mathrm{mg} / 100 \mathrm{~g}$

Table 2, figure 3 and figure 4 shows the manganese content of wild edible mushrooms in this study the highest levels of manganese was in Chlorophyllum rhacodes was $0.12 \mathrm{mg} / 100 \mathrm{~g}$, whereas the lowest levels of manganese was in Agaricus silvicola was $0.10 \mathrm{mg} / 100 \mathrm{~g}$.

\subsection{Amino Acids Content}

Table 3, figure 5 and figure 6 shows the arginine contents of wild edible mushrooms Agaricus bisporus, Chlorophyllum rhacodes, Agaricus lutosus, Volvariella volvacea, Agaricus impudicus, Agaricus arvensis, Agaricus silvicola and the commercial sample (Agaricus bisporus). The highest values of arginine were in Chlorophyllum rhacodes $(6.40 \mathrm{mg} / 100 \mathrm{~g})$ whereas the lowest values of arginine was in Agaricus arvensis was $(6.30 \mathrm{mg} / 100 \mathrm{~g})$. Tseng and Mau (1999) [20] reported that the arginine content of some wild edible mushrooms was in Agaricus bisporus (3.83 mg/100g).

Table 3, figure 5 and figure 6 shows the histidine content of wild edible mushrooms. The highest values of histidine were in Chlorophyllum rhacodes $(2.20 \mathrm{mg} / 100 \mathrm{~g})$, whereas the lowest values of histidine were in Agaricus impudicus $(1.90 \mathrm{mg} / 100 \mathrm{~g})$. Crisan and sands (1978) [9] reported that the histidine content of some wild edible mushrooms was in Agaricus bisporus $(2.7 \mathrm{mg} / 100 \mathrm{~g})$ and Volvariella volvacea (3.8 $\mathrm{mg} / 100 \mathrm{~g})$.

Table 3, figure 5 and figure 6 shows the lysine content wild edible mushrooms. The highest values of lysine were in Chlorophyllum rhacodes $(5.10 \mathrm{mg} / 100 \mathrm{~g})$, whereas the lowest values of lysine were in Agaricus bisporus (5.00 mg/100g). Crisan and sands (1978)[9] reported that the lysine content of some wild edible mushrooms was in Agaricus bisporus (9.1 $\mathrm{mg} / 100 \mathrm{~g})$ and Volvariella volvacea $(7.1 \mathrm{mg} / 100 \mathrm{~g})$.

Table 3, figure 5 and figure 6 shows the tryptophan content of wild edible mushrooms. The highest values of tryptophan were in Agaricus bisporus (0.90 mg/100g), whereas the lowest values of tryptophan was in Chlorophyllum rhacodes $(0.88 \mathrm{mg} / 100 \mathrm{~g})$. Crisan and sands (1978) [9] reported that the tryptophan content of some wild edible mushrooms was in Agaricus bisporus $(2.0 \mathrm{mg} / 100 \mathrm{~g})$ and Volvariella volvacea (1.5 mg/100g).

Table 3, figure 5 and figure 6 shows the phenylalanine content of wild edible mushrooms. The highest values of phenylalanine was in Agaricus arvensis $(2.10 \mathrm{mg} / 100 \mathrm{~g})$, whereas the lowest values of phenylalanine was in Agaricus silvicola (2.00 mg/100g). Crisan and sands (1978) [9] reported that the phenylalanine content of some wild edible mushrooms was in Agaricus bisporus (4.2 mg/100g) and Volvariella volvacea $(2.6 \mathrm{mg} / 100 \mathrm{~g})$.

Table 3, figure 5 and figure 6 shows the methionine of wild edible mushrooms. The highest values of methionine was in Agaricus bisporus (1.15 mg/100g), whereas the lowest values of methionine was in Agaricus silvicola (1.00 $\mathrm{mg} / 100 \mathrm{~g}$ ). Crisan and sands (1978) [9] reported that the methionine content of some wild edible mushrooms was in 
Agaricus bisporus $(0.9 \mathrm{mg} / 100 \mathrm{~g})$ and Volvariella volvacea $(1.1 \mathrm{mg} / 100 \mathrm{~g})$.

Table 3, figure 5 and figure 6 shows the threonine content of wild edible mushrooms. The highest values of threonine was in Agaricus bisporus (4.10 mg/100g), whereas the lowest values of threonine was in Volvariella volvacea (4.05 $\mathrm{mg} / 100 \mathrm{~g}$ ), the values within all samples showed no significantly difference $(\mathrm{P} \leq 0.05)$. Crisan and sands (1978) [9] reported that the threonine content of some wild edible mushrooms was in Agaricus bisporus $(5.5 \mathrm{mg} / 100 \mathrm{~g})$ and Volvariella volvacea $(3.5 \mathrm{mg} / 100 \mathrm{~g})$.

Table 3, figure 5 and figure 6 shows the leucine content of wild edible mushrooms. The highest values of leucine was in Chlorophyllum rhacodes $(4.10 \mathrm{mg} / 100 \mathrm{~g})$, whereas the lowest values of leucine was in commercial sample (Agaricus bisporus) was $(3.90 \mathrm{mg} / 100 \mathrm{~g})$. The values within all samples showed significantly difference $(\mathrm{P} 0 \leq 0.05)$. Crisan and sands (1978) [9] reported that the leucine content of some wild edible mushrooms was in Agaricus bisporus $(7.5 \mathrm{mg} / 100 \mathrm{~g}$ ) and Volvariella volvacea $(4.5 \mathrm{mg} / 100 \mathrm{~g})$.

Table 3, figure 5 and figure 6 shows the isoleucine content of wild edible mushrooms. The highest values of isoleucine was in Chlorophyllum rhacodes $(5.70 \mathrm{mg} / 100 \mathrm{~g})$, whereas the lowest values of isoleucine was in Agaricus bisporus (5.56 $\mathrm{mg} / 100 \mathrm{~g})$. The values within all samples are not significantly $(\mathrm{P} \leq 0.05)$ different. Crisan and sands (1978) [9] reported that the isoleucine content of some wild edible mushrooms was in Agaricus bisporus $(4.5 \mathrm{mg} / 100 \mathrm{~g})$ and Volvariella volvacea (3.4 mg/100g).

Table 3, figure 5 and figure 6 shows the valine content of wild edible mushrooms. The highest values of valine was in Agaricus bisporus $(4.50 \mathrm{mg} / 100 \mathrm{~g})$, whereas the lowest values of valine was in Agaricus arvensis $(4.20 \mathrm{mg} / 100 \mathrm{~g})$. The values within all samples are highly significantly $(\mathrm{P} \leq 0.05)$ different. Crisan and sands (1978) [9] reported that the valine content of some wild edible mushrooms was in Agaricus bisporus $(2.5 \mathrm{mg} / 100 \mathrm{~g})$ and Volvariella volvacea $(5.4$ $\mathrm{mg} / 100 \mathrm{~g})$.

Table 1. Chemical composition of edible mushroom ( $\mathrm{g} / 100 \mathrm{~g}$ dry weight basis).

\begin{tabular}{|c|c|c|c|c|c|c|}
\hline Sample & Moisture (\%) & Fat $(\%)$ & Crude fiber (\%) & Total CHO (\%) & Crude protein \% (Nx4.38) & Ash (\%) \\
\hline $\mathrm{A}$ & $5.26^{\mathrm{b}} \pm 0.00$ & $1.19^{\mathrm{g}} \pm 0.04$ & $18.00^{\mathrm{b}} \pm 1.00$ & $77.91^{\mathrm{a}} \pm 1.00$ & $19.41^{\mathrm{g}} \pm 0.01$ & $1.47^{\mathrm{a}} \pm 0.01$ \\
\hline B & $5.26^{\mathrm{b}} \pm 0.00$ & $1.98^{\mathrm{d}} \pm 0.05$ & $9.30^{\mathrm{e}} \pm 0.10$ & $29.93^{\mathrm{g}} \pm 1.00$ & $21.02^{\mathrm{e}} \pm 0.02$ & $1.37^{\mathrm{b}} \pm 0.01$ \\
\hline $\mathrm{C}$ & $5.26^{\mathrm{b}} \pm 0.00$ & $2.99^{\mathrm{a}} \pm 0.00$ & $9.55^{\mathrm{e}} \pm 0.00$ & $54.01^{\mathrm{b}} \pm 0.01$ & $23.29^{\mathrm{d}} \pm 0.01$ & $0.59^{\mathrm{d}} \pm 0.00$ \\
\hline $\mathrm{D}$ & $11.11^{\mathrm{a}} \pm 0.00$ & $2.90^{\mathrm{b}} \pm 0.00$ & $12.88^{\mathrm{d}} \pm 0.10$ & $49.98^{c} \pm 0.01$ & $34.14^{\mathrm{a}} \pm 0.12$ & $0.45^{\mathrm{e}} \pm 0.00$ \\
\hline $\mathrm{E}$ & $5.26^{\mathrm{b}} \pm 0.00$ & $0.94^{\mathrm{h}} \pm 0.02$ & $23.86^{\mathrm{a}} \pm 0.01$ & $26.76^{\mathrm{h}} \pm 0.01$ & $20.06^{\mathrm{f}} \pm 0.01$ & $0.22^{\mathrm{h}} \pm 0.00$ \\
\hline $\mathrm{F}$ & $11.11^{\mathrm{a}} \pm 0.00$ & $1.52^{\mathrm{f}} \pm 0.01$ & $13.85^{\mathrm{c}} \pm 0.01$ & $42.37^{\mathrm{e}} \pm 0.01$ & $27.93^{\mathrm{b}} \pm 0.01$ & $0.43^{\mathrm{f}} \pm 0.00$ \\
\hline $\mathrm{H}$ & $5.26^{\mathrm{b}} \pm 0.00$ & $1.85^{\mathrm{e}} \pm 0.01$ & $9.78^{\mathrm{e}} \pm 0.01$ & $32.26^{\mathrm{f}} \pm 0.01$ & $24.26^{\mathrm{c}} \pm 0.01$ & $0.60^{c} \pm 0.00$ \\
\hline P-value & $0.003^{* *}$ & $0.00^{* *}$ & $0.00^{* *}$ & $0.00^{* *}$ & $0.00^{* *}$ & $0.00^{* *}$ \\
\hline $\operatorname{Lsd}_{0.05}$ & 0.0007292 & 0.0005474 & 0.6193 & 0.8654 & 0.6193 & 0.0005474 \\
\hline $\mathrm{SE} \pm$ & 0.0002236 & 0.0001826 & 0.2066 & 0.2887 & 0.2066 & 0.0001826 \\
\hline
\end{tabular}

Mean \pm SD value (s) having different superscript ( $\mathrm{s}$ ) letters in a column are significantly different $(\mathrm{P} \leq 0.05)$ according to DMRT.

Key:

$\mathrm{A} \equiv$ Agaricus bisporus $\mathrm{B} \equiv$ Chlorophyllum rhacodes $* \equiv$ significantly different .

$\mathrm{C} \equiv$ Agaricus lutosus $\mathrm{D} \equiv$ Volvariella volvacea $* * \equiv$ highly significantly different.

$\mathrm{E} \equiv$ Agaricus impudicus $\mathrm{F} \equiv$ Agaricus arvensis $N S \equiv$ not significantly different .

$\mathrm{G} \equiv$ Agaricus silvicola $\mathrm{H} \equiv$ Agaricus bisporus (commercial sample).

Table 2. Minerals content of edible mushroom (dry weight).

\begin{tabular}{|c|c|c|c|c|c|c|c|c|}
\hline Sample & $\mathrm{Ca}(\mathrm{mg} / \mathrm{kg}))$ & Mg (mg/kg) & P (mg/kg) & K (mg/kg) & $\mathrm{Fe}(\mathrm{mg} / 100 \mathrm{~g})$ & Zn (mg/100g) & $\mathrm{Cu}$ (mg/100g) & Mn (mg/100g) \\
\hline $\mathrm{A}$ & $6.35^{\mathrm{c}} \pm 0.07$ & $3.10^{\mathrm{c}} \pm 0.00$ & $2.30^{\mathrm{ab}} \pm 0.00$ & $21.20^{\mathrm{a}} \pm 0.00$ & $1.55^{\mathrm{a}} \pm 0.07$ & $0.51^{\mathrm{b}} \pm 0.00$ & $0.11^{\mathrm{a}} \pm 0.01$ & $0.11^{\mathrm{b}} \pm 0.01$ \\
\hline B & $7.45^{\mathrm{b}} \pm 0.07$ & $3.70^{\mathrm{b}} \pm 0.28$ & $2.25^{\mathrm{ab}} \pm 0.07$ & $21.20^{\mathrm{a}} \pm 0.00$ & $1.40^{\text {bcd }} \pm 0.00$ & $0.51^{\mathrm{b}} \pm 0.00$ & $0.10^{\mathrm{b}} \pm 0.00$ & $0.12^{\mathrm{a}} \pm 0.01$ \\
\hline $\mathrm{C}$ & $8.60^{\mathrm{a}} \pm 0.00$ & $5.50^{\mathrm{a}} \pm 0.14$ & $2.45^{\mathrm{ab}} \pm 0.21$ & $21.40^{\mathrm{a}} \pm 0.28$ & $1.45^{\mathrm{abc}} \pm 0.07$ & $0.51^{\mathrm{b}} \pm 0.00$ & $0.10^{\mathrm{b}} \pm 0.00$ & $0.11^{\mathrm{b}} \pm 0.01$ \\
\hline $\mathrm{D}$ & $5.80^{\mathrm{d}} \pm 0.14$ & $3.07^{\mathrm{c}} \pm 0.07$ & $2.50^{\mathrm{a}} \pm 0.14$ & $21.30^{\mathrm{a}} \pm 0.00$ & $1.30^{\mathrm{d}} \pm 0.00$ & $0.52^{\mathrm{a}} \pm 0.01$ & $0.10^{\mathrm{b}} \pm 0.00$ & $0.12^{\mathrm{a}} \pm 0.01$ \\
\hline E & $7.45^{b} \pm 0.07$ & $3.70^{\mathrm{b}} \pm 0.14$ & $2.30^{\mathrm{ab}} \pm 0.00$ & $21.40^{\mathrm{a}} \pm 0.14$ & $1.40^{\text {bcd }} \pm 0.00$ & $0.51^{\mathrm{b}} \pm 0.00$ & $0.11^{\mathrm{a}} \pm 0.01$ & $0.11^{\mathrm{b}} \pm 0.01$ \\
\hline $\mathrm{F}$ & $8.40^{\mathrm{a}} \pm 0.00$ & $3.10^{\mathrm{c}} \pm 0.00$ & $2.50^{\mathrm{a}} \pm 0.14$ & $21.50^{\mathrm{a}} \pm 0.14$ & $1.50^{\mathrm{ab}} \pm 0.00$ & $0.52^{\mathrm{a}} \pm 0.01$ & $0.11^{\mathrm{a}} \pm 0.01$ & $0.12^{\mathrm{a}} \pm 0.01$ \\
\hline G & $6.40^{c} \pm 0.14$ & $3.80^{\mathrm{b}} \pm 0.14$ & $2.15^{\mathrm{b}} \pm 0.07$ & $21.20^{\mathrm{a}} \pm 0.00$ & $1.35^{\mathrm{cd}} \pm 0.07$ & $0.51^{\mathrm{b}} \pm 0.00$ & $0.10^{\mathrm{b}} \pm 0.00$ & $0.10^{c} \pm 0.00$ \\
\hline $\mathrm{H}$ & $8.55^{\mathrm{a}} \pm 0.07$ & $3.70^{\mathrm{b}} \pm 0.28$ & $2.45^{\mathrm{ab}} \pm 0.21$ & $21.40^{\mathrm{a}} \pm 0.28$ & $1.40^{\mathrm{bcd}} \pm 0.00$ & $0.51^{\mathrm{b}} \pm 0.01$ & $0.10^{\mathrm{b}} \pm 0.00$ & $0.12^{\mathrm{a}} \pm 0.01$ \\
\hline P-value & $0.0002^{* *}$ & $0.005^{* *}$ & $0.04867^{*}$ & $0.4501^{\mathrm{NS}}$ & $0.0074^{* *}$ & $0.0456^{*}$ & $0.050^{*}$ & $0.0491^{*}$ \\
\hline $\operatorname{Lsd}_{0.05}$ & 0.2063 & 0.3859 & 0.3007 & 0.3646 & 0.1031 & 0.0007292 & 0.0007292 & 0.0007292 \\
\hline $\mathrm{SE} \pm$ & 0.06325 & 0.1183 & 0.0922 & 0.1118 & 0.03162 & 0.0002236 & 0.0002236 & 0.0002236 \\
\hline
\end{tabular}

Mean \pm SD value (s) having different superscript (s) letters in a column are significantly different (P $\leq 0.05)$ according to DMRT.

Key:

$\mathrm{A} \equiv$ Agaricus bisporus $\mathrm{B} \equiv$ Chlorophyllum rhacodes $* \equiv$ significantly different .

$\mathrm{C} \equiv$ Agaricus lutosus $\mathrm{D} \equiv$ Volvariella volvacea $* * \equiv$ highly significantly different.

$\mathrm{E} \equiv$ Agaricus impudicus $\mathrm{F} \equiv$ Agaricus arvensis $\mathrm{NS} \equiv$ not significantly different.

$\mathrm{G} \equiv$ Agaricus silvicola $\mathrm{H} \equiv$ Agaricus bisporus (commercial sample). 
Table 3. Amino acids content of edible mushroom (mg/100 $g$ dry weight).

\begin{tabular}{|c|c|c|c|c|c|c|c|c|c|c|}
\hline Sample & Arginine & Histidine & Lysine & Tryptophan & Phenylalanine & Methionine & Threonine & Leucine & Isoleucine & Valine \\
\hline A & $6.35^{\mathrm{ab}} \pm 0.07$ & $2.15^{\mathrm{ab}} \pm 0.07$ & $5.00^{\mathrm{b}} \pm 0.00$ & $0.90^{\mathrm{a}} \pm 0.00$ & $2.00^{\mathrm{b}} \pm 0.00$ & $1.15^{\mathrm{a}} \pm 0.07$ & $4.10^{\mathrm{a}} \pm 0.00$ & $4.00^{\mathrm{b}} \pm 0.00$ & $5.56^{\mathrm{a}} \pm 0.07$ & $4.50^{\mathrm{a}} \pm 0.07$ \\
\hline B & $6.40^{\mathrm{a}} \pm 0.00$ & $2.20^{\mathrm{a}} \pm 0.00$ & $5.10^{\mathrm{a}} \pm 0.00$ & $0.88^{\mathrm{c}} \pm 0.0$ & $2.00^{\mathrm{b}} \pm 0.00$ & $1.00^{\mathrm{b}} \pm 0.00$ & $4.10^{\mathrm{a}} \pm 0.00$ & $4.10^{\mathrm{a}} \pm 0.00$ & $5.70^{\mathrm{a}} \pm 0.00$ & $4.50^{\mathrm{a}} \pm 0.00$ \\
\hline $\mathrm{C}$ & $6.30^{\mathrm{b}} \pm 0.00$ & $2.10^{\mathrm{bc}} \pm 0.00$ & $5.00^{\mathrm{b}} \pm 0.00$ & $0.89^{\mathrm{b}} \pm 0.00$ & $2.00^{\mathrm{b}} \pm 0.00$ & $1.00^{\mathrm{b}} \pm 0.00$ & $4.10^{\mathrm{a}} \pm 0.00$ & $4.10^{\mathrm{a}} \pm 0.00$ & $5.70^{\mathrm{a}} \pm 0.00$ & $4.40^{\mathrm{ab}} \pm 0.00$ \\
\hline $\mathrm{E}$ & $6.40^{\mathrm{a}} \pm 0.00$ & $1.90^{\mathrm{e}} \pm 0.00$ & $5.10^{\mathrm{a}} \pm 0.00$ & $0.90^{\mathrm{a}} \pm 0.00$ & $2.00^{\mathrm{b}} \pm 0.00$ & $1.00^{\mathrm{b}} \pm 0.00$ & $4.10^{\mathrm{a}} \pm 0.00$ & $3.90^{\mathrm{c}} \pm 0.00$ & $5.65^{\mathrm{a}} \pm 0.07$ & $4.30^{b c} \pm 0.00$ \\
\hline $\mathrm{F}$ & $6.30^{\mathrm{b}} \pm 0.00$ & $2.10^{\mathrm{bc}} \pm 0.00$ & $5.00^{\mathrm{b}} \pm 0.00$ & $0.90^{\mathrm{a}} \pm 0.00$ & $2.10^{\mathrm{a}} \pm 0.00$ & $1.00^{\mathrm{b}} \pm 0.00$ & $4.10^{\mathrm{a}} \pm 0.00$ & $3.90^{\mathrm{c}} \pm 0.00$ & $5.60^{\mathrm{a}} \pm 0.00$ & $4.20^{\mathrm{c}} \pm 0.14$ \\
\hline G & $6.40^{\mathrm{a}} \pm 0.00$ & $2.00^{\mathrm{d}} \pm 0.00$ & $5.00^{\mathrm{b}} \pm 0.00$ & $0.90^{\mathrm{a}} \pm 0.00$ & $2.00^{\mathrm{b}} \pm 0.00$ & $1.00^{\mathrm{b}} \pm 0.00$ & $4.10^{\mathrm{a}} \pm 0.00$ & $3.90^{\mathrm{c}} \pm 0.00$ & $5.65^{\mathrm{a}} \pm 0.07$ & $4.50^{\mathrm{a}} \pm 0.00$ \\
\hline P-value & $0.0047^{* *}$ & $0.0007^{* *}$ & $0.00^{* *}$ & $0.0494^{*}$ & $0.00^{* *}$ & $0.003^{* *}$ & $0.4934^{\mathrm{NS}}$ & $0.0001^{* *}$ & $0.4934^{\mathrm{NS}}$ & $0.0086^{* *}$ \\
\hline $\operatorname{Lsd}_{0.05}$ & 0.07292 & 0.07292 & 0.0007292 & 0.0007292 & 0.0007292 & 0.07292 & 0.07292 & 0.0007292 & 0.1031 & 0.1458 \\
\hline $\mathrm{SE} \pm$ & 0.02236 & 0.2236 & 0.0002236 & 0.0002236 & 0.002236 & 0.02236 & 0.02236 & 0.0002236 & 0.03162 & 0.04472 \\
\hline
\end{tabular}

Mean \pm SD value (s) having different superscript (s) letters in a column are significantly different $(\mathrm{P} \leq 0.05)$ according to DMRT.

Key:

$\mathrm{A} \equiv$ Agaricus bisporus $\mathrm{B} \equiv$ Chlorophyllum rhacodes $* \equiv$ significantly different.

$\mathrm{C} \equiv$ Agaricus lutosus $\mathrm{D} \equiv$ Volvariella volvacea $* * \equiv$ highly significantly different.

$\mathrm{E} \equiv$ Agaricus impudicus $\mathrm{F} \equiv$ Agaricus arvensis $N S \equiv$ not significantly different.

$\mathrm{G} \equiv$ Agaricus silvicola $\mathrm{H} \equiv$ Agaricus bisporus (commercial sample).

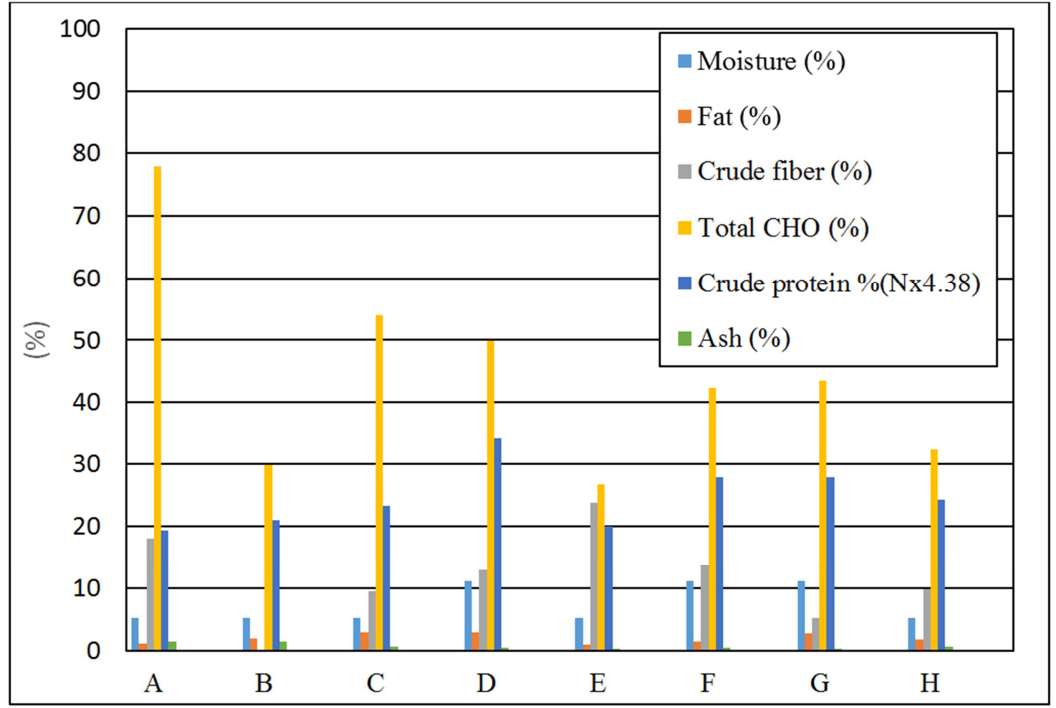

Figure 1. Chemical composition of edible mushroom.

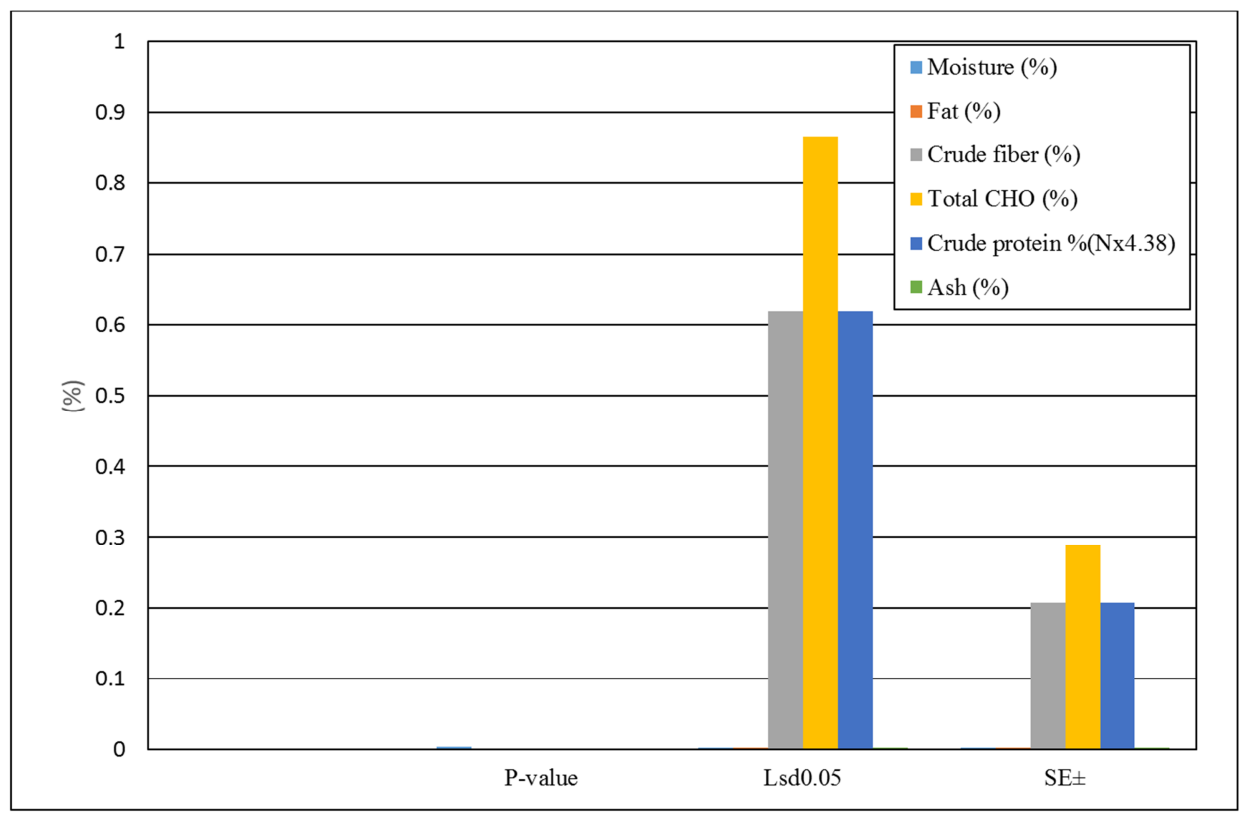

Figure 2. Chemical composition of edible mushroom (P-value, $L s d_{0.05}, S E \pm$ ). 


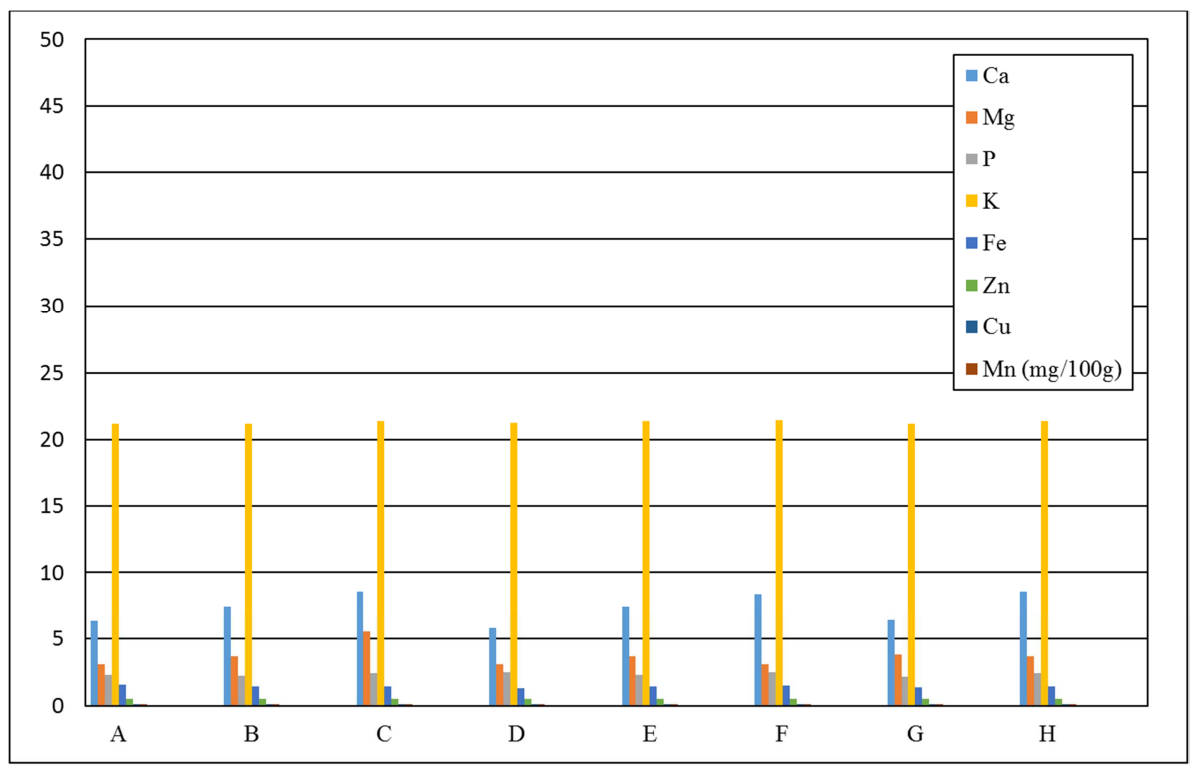

Figure 3. Minerals content of edible mushroom (dry weight).

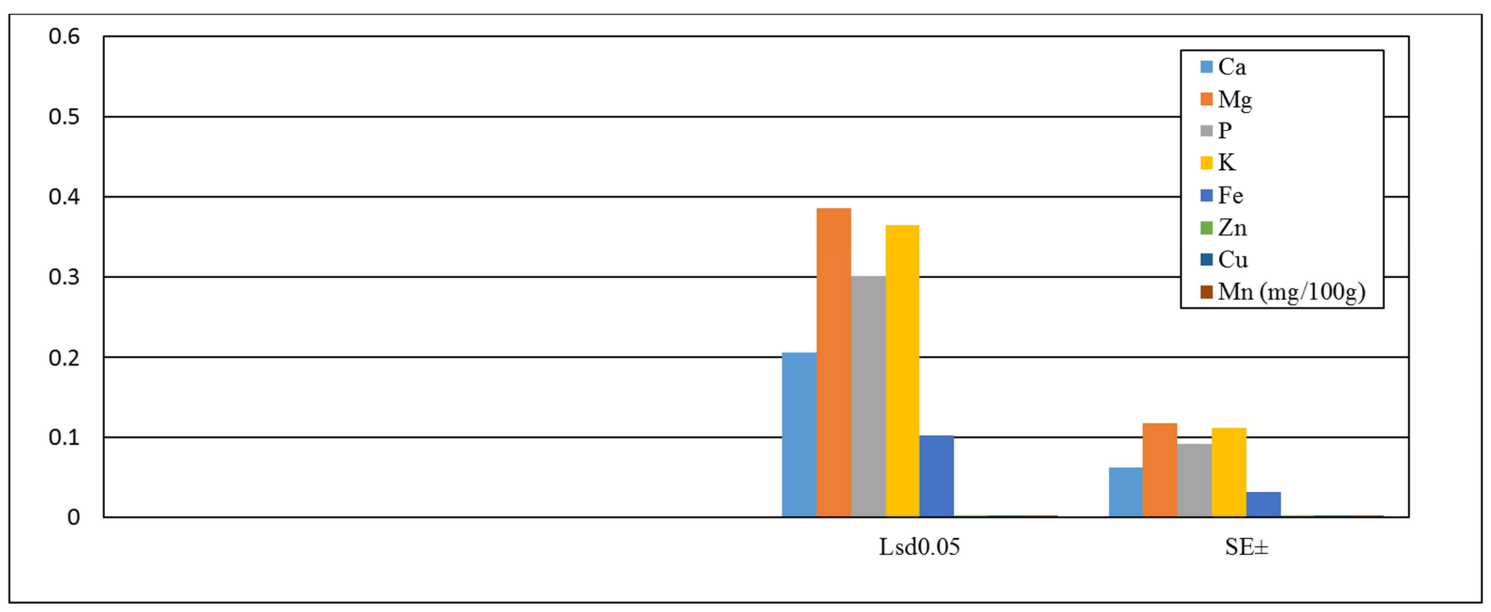

Figure 4. Minerals content of edible mushroom ( $\left.L s d_{0.05}, S E \pm\right)$.

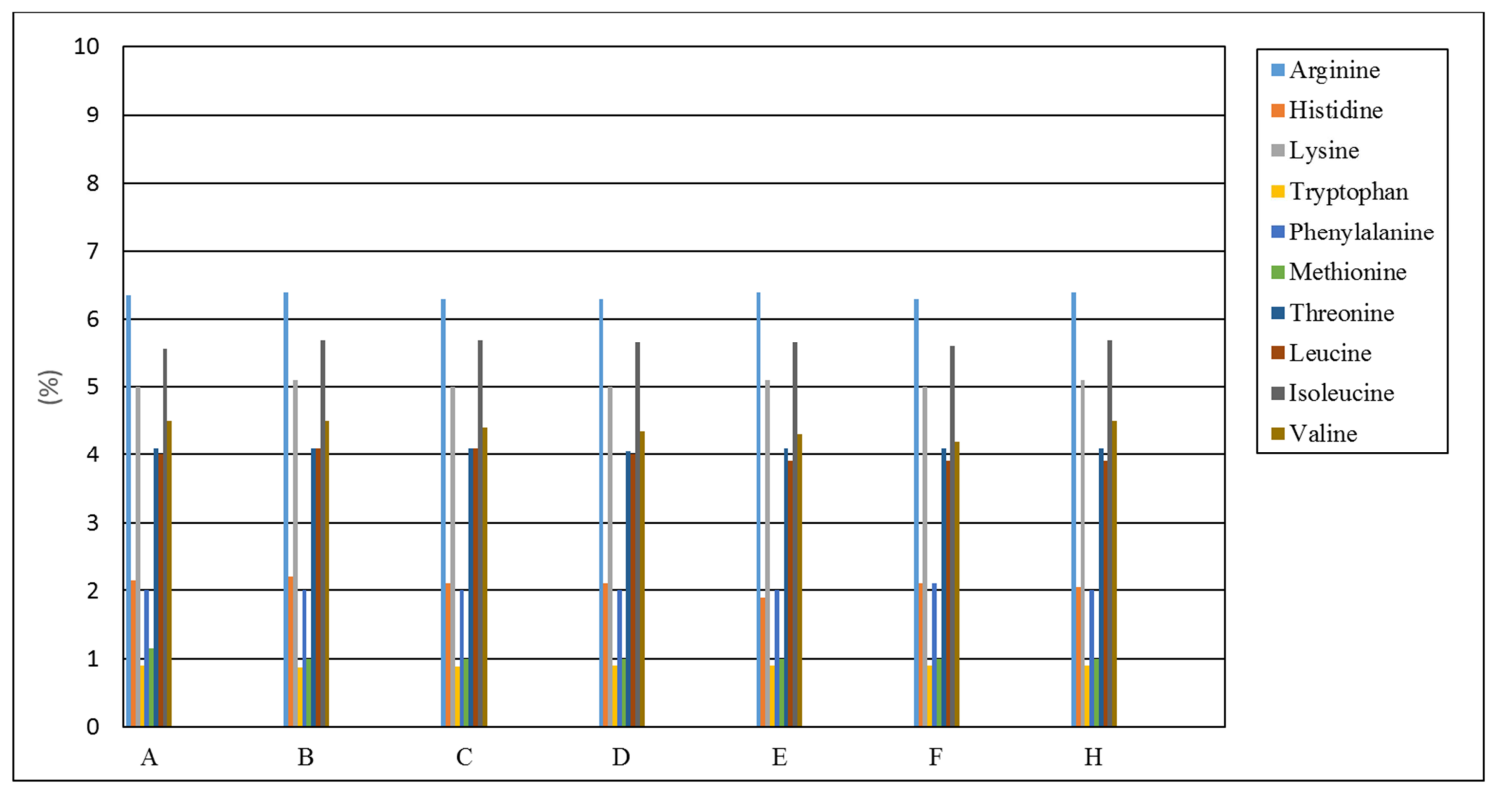

Figure 5. Amino acids content of edible mushroom (mg/100 g dry weight). 


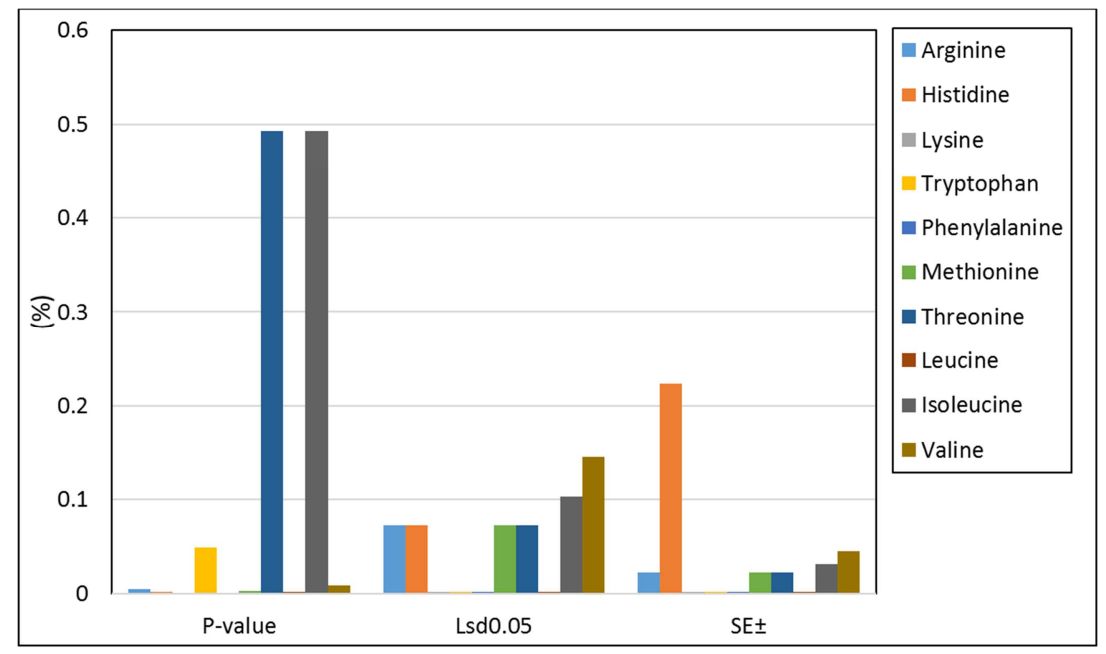

Figure 6. Amino acids content of edible mushroom (P-value, Lsd $\left.d_{0.05}, S E \pm\right)$.

\section{Conclusions}

1. Based on the results obtained in this study it can be concluded that the studied edible mushroom samples (seven of them are wild varieties collected from Blue Nile State) are nontoxic.

2. These mushrooms are good sources of protein, minerals and essential amino acids.

3. Also, these varieties could be entered as dietary supplements in the local people's food to increase the nutritional value and thus a cheap protein and mineral source will be available to all people during the rainfall season.

4. The study revealed that the proximate composition, mineral and essential amino acids are of edible mushroom sample ware considerable amount.

\section{Acknowledgements}

First and finally my all thanks to ALLAH for his generosity to complete this work. My thanks are extended to Sudan University of Science and Technology. I would like also to express my appreciation to my supervisor Dr. Ebrahim Alfaig Alnoor who has cheerfully answered my queries, provided me with materials, checked my examples, assisted me in a myriad ways with the writing and helpfully commented on earlier drafts of this research, also galore thanks to Dr. Moawia Yahia Babiker for samples analysis consulting and especial thanks to Dr. Sara Ahmed Mohamed Saad at the National Center for Research, Department of Environmental Research and Desertification research institute who helped me in the analysis. Also I am very grateful to my friend Yassin Abdallah Yahia and Special thanks to Mrs. Rania Ramadan in mushroom production unit, Al Zaiem Al Azhari University, and Magdi Hashem at the Center Laboratory for the National Central for Research.

God bless all those who helped me and placed their valuable time and knowledge during the research of the study.

\section{References}

[1] Abdalla, R. (2015). Morphological and chemical characteristics of some edible and Medicinal wild mushrooms of Khartoum and Sinner State. A dissertation submitted to Al Zaiem AL Azhari University in partial fulfillment of requirements for the degree of Master of Science in Agriculture.

[2] Alves, M. J.; Ferreira, I. C.; Dias, J., Teixeira, V.; Martins, A. and Pintado, M. (2012). A review on antimicrobial activity of mushroom (Basidiomycetes) extracts and isolated compounds. Planta Medica, 78 (16): 1707-1718.

[3] AOAC (2003). Official Methods of Analysis of Association of Official Analytical Chemists. $17^{\text {th }}$. Washington, D. C.

[4] AOAC (2005). Official Methods of Analysis of Association of Official Analytical Chemists. $18^{\text {th }}$. Washington, D. C.

[5] AOAC (2006). Official Methods of Analysis. $18^{\text {th }}$ Edn. Association of Official Analytical Chemists Inc., Arlington, TX., USA.

[6] Barros, L.; Baptista, P.; Estevinho, L. M. and Ferreira, I. (2007). Effect of fruiting body maturity stage on chemical composition and antimicrobial activity of lactariussp. Mushrooms. J. Agric. Food Chemistry, 55, 8766-8771. http://dx.doi.org/10.1021/jf071435+.

[7] Chang, S. T. and Buswell, J. A. (1996). Mushroom nutriceuticals, World J. Microbiol. Biotechnol., 12: 473-476.

[8] Chang, S. T. and Miles, P. G. (1989) Edible mushrooms and their cultivation: CRC press: Baco Raton. FL 1-38.

[9] Crisan, E. W. and Sands, A. (1978). A Nutritional value. In: Chang S. T. and Hayes W. A. (Eds.). The biology and cultivation of edible mushrooms. Academic press, New York, pp. 172-189.

[10] Elmer, P. (1996). Atomic Absorption Spectroscopy Analytical Methods. The Perkin Elmer Corporation, 132-145.

[11] Ferreira, I. C. F. R.; Barros, L. and Abreu, R. M. V. (2009). Antioxidant in Wild mushrooms. Current Medicinal Chemistry, 16, 1543-1560. 
[12] Ferreira, I. C. F. R.; Vaz, J. A.; Vasconcelos, M. H. and Martins, A. (2010). Compounds from Wild Mushrooms with Antitumor Potential. Anti-Cancer Agents in Medicinal Chemistry, 10: 424-436.

[13] Heleno, S. A.; Barros, L.; Sousa, M. J.; Martins, A. and Ferreira, I. C. F. R. (2009). Study and characterization of selected nutrients in wild mushrooms from Portugal by gas chromatography and high-performance liquid chromatography. Microchemical Journal, 93: 195-199.

[14] Kalac, P. (2012). Chemical composition and nutritional value of European species of wild growing mushrooms, In Mushrooms: types, properties and nutrition. Editors: S. Andres and N. Baumann. Nova Science Publishers, 130-151.

[15] Mshandete, A. M. and Cuff, J. (2007). Proximate and nutrient composition of three types of indigenous edible wild mushrooms grown in Tanzania and their utilization prospects. African Journal of Food, Nutrition and Development, 7 (6). ISSN 1684-5374.
[16] Mushroom expert website. (2008). By Michael Kuo http://www.mushroomexpert.com/.

[17] Mycokey Software program version 4.1. (2016). Jens, H. Peterson, Thomas Lassoe, http://www.mycokey.com/.

[18] Saiqa, S.; Haq, N. B.; Muhammad, A. H. and Ali, M. A. (2008). Studies on chemical composition and nutritive evaluation of wild edible mushrooms. Iran. J. Chem. Chem. Eng. Research Note, 27 (3): pp 151-154.

[19] Shiuan, C. (2004). Anticancer activities of white button mushrooms. Journal of Nutrition Bethesda, 134 (12S): 3532S$3533 \mathrm{~S}$.

[20] Tseng, Y. H. and Mau, J. L. (1999). 5o-nucleotides in mushrooms, Agaricus bisporus, during post-harvest storage. Journal of the Science of Food and Agriculture, 79: 15191523.

[21] Yu, S.; Weaver, V.; Martin, K. and Cantorna, M. T. (2009). Effect of whole mushrooms during inflammation BMC Immunology Journal. 10 (1): 12. 